\title{
STUDY OF ORGANOCHLORINE
}

\section{PESTICIDE RESIDUES LEVEL IN FRESH AND DRIED TOMATOE FROM SELECTED FARMLANDS IN ZAMFARA STATE, NIGERIA}

\author{
Momoh Shaibu, M.A.T. Suleiman, R.A.lafia-Araga, S.O. Salihu \\ Department of Chemistry, Federal University of Technology P.M.B 65, \\ Minna, Niger State, Nigeria
}

\begin{abstract}
In this study, organochlorine pesticide (OCP) residues level in fresh and dried tomato from selected farmland in Zamfara State, Nigeria were determined in fresh and sundried portion of the samples. QuEChERS and GC-MS were used for sample preparation and analysis respectively. The results obtained shows the presence of OCPs residues including; $\alpha \mathrm{HCH}, \beta \mathrm{HCH}$, Endosulfan I\&II, isodrin, DDM, deildrin, and mitotane with concentration of $3.669 \mathrm{mg} / \mathrm{kg}, \quad 0.0100 \mathrm{mg} / \mathrm{kg}$, $\quad 0.1714 \mathrm{mg} / \mathrm{kg}, \quad 0.129 \mathrm{mg} / \mathrm{kg}, \quad 0.0067 \mathrm{mg} / \mathrm{kg}$, $0.0054 \mathrm{mg} / \mathrm{kg}, \quad 0.2734 \mathrm{mg} / \mathrm{kg}$. The $\alpha \mathrm{HCH}$, endosulfan, isodrin and mitotane were above the maximum residual limit (MRL) in the fresh samples, below the MRL in dried samples, while endosulfan II, mitotane, and deildrine were below detection limit in dried tomato extracts. On the other hand $\alpha \mathrm{HCH}$ and mitotane has hazard index of 2.737 and 1.012 respectively. It is therefore, recommended to the regulatory institutions in Nigeria for effective awareness and educates the farmers on the health effect of pesticides residues in our food and environment. Also encourage drying process when a high level of pesticide residues are suspected in the tomatoes.
\end{abstract}

Keynote: Organochlorine, Pesticide residues, Fresh Tomato, GC-MS.

\section{INTRODUCTION}

Tomatoes (Lycoperiscum esculentum, solanum Lycoperiscum.) belong to the solanacea family and correspond to one of the most widely grown vegetable in the world. The fruit vegetable is typically produced in the spring summer season, but in many country including Nigeria, it is produced throughout the years with the help of irrigation farming [5]. It is a basic ingredient of many meals in
Nigeria especially, the sauces and stews which accompany most traditional dishes. The fruit can also be consumed raw in salads or used to make juices [8]. Uncontaminated tomatoes play a vital role in human dietary intake; it help managing blood pressure, healthy hair, prevent cancer, maintained kidney, maintained sugar level in the blood, and provide essential antioxidant such as vitamin $\mathrm{C}$ and $\mathrm{A}$. that is why tomato consumption is usually for healthy and balanced diet [4], [5] [8] The demand for tomatoes over shadows the supply, the challenge is attributed to the seasonality and lack of storage facility and inadequate post-harvest handling of tomatoes [3], [6].

Drying of tomatoes becomes the only way farmers can economically provide alternative to fresh ones, which are available in most vegetables, markets [4]. Drying is an important and traditional process of removing the moisture from the food. The basic principle of drying is to prevent microorganisms such as bacteria, and fungi, which required water for their growth and multiplication.

Tomato farmers used pesticide such as organanochlorine to control pest and disease in order to protect the crops from pest attack and good yield. This pesticides are used indiscriminately by farmers to mitigate loses of tomato in the farm because they are cheap and readily available in market [25] [2].

In Nigeria, farmers and consumers of this vegetable fruits faces an immense risk of exposures to this toxic chemical use to controlled pest, some of these toxic chemicals are banned or restricted in Nigeria or in other countries [22]. Wrong application techniques and time of application of these chemicals to the vegetable, or the use of unsuitable equipment for application expose farmers and farm products to the 
risks of residual deposition [15]. There are some pesticides residues that are unavoidable even when spraying are done in accordance with good agricultural practice. Organochlorine compounds are considered persistent organic pollutants, a category of chemicals that include: Dichlorodiphenyltrichloroethane (DDT), methoxychlor, Dieldrin, Chlordane, Toxaphene, Kepone, lindane, Benzene hexachloride, endrin, and mirrex.

In Nigeria, the following organochlorine pesticides have been banned by NAFDAC dichlorodiphenyltrichloroethane (DDT), hexachlorocyclohexanes (HCHs), aldrin, dieldrin, endrin, and heptachlor) because of concerns on the environment and human health.

Despite the banned on most of the toxic organochlorine compounds, they are still in used in developing countries like Nigeria for pest control. This continues used of organochlorine pesticides has remained a matter of international concern because of their residual persistence in agricultural products [14],[22],[24],[15].

\section{Maximum residual limit of organochlorine pesticide (MRL)}

Residues is defined by [17] as any substance or mixture of substance in food for man or animals resulting from the use of pesticide and includes any specified derivatives, such as degradation and conversion products, metabolites, reaction products, and impurities that are considered to be of toxicological significance.

Each country setup it own maximum residue limit (MRL) and Acceptable Daily intake (ADI) of pesticide residues in their agricultural products. Nigeria used residual limits established by food and Agriculture organization of the United Nations (FAO) and world health organization (WHO) [23]. When the residues are more than MRL, it poses health risk to human and environment. Short term and long term impacts in human body are damage to reproductive system, and immune system [25]. WHO has reported that roughly three million pesticide poisoning occurs annually and results to 220,000 death worldwide. Farmers all over the world used both approved and banned pesticide to control pest and disease of tomato as reported [17].

\section{MATERIALS AND METHODS}

\section{Reagents}

Solvent, reagents and pesticides standard were of analytical grade and obtained from sigma and Co. The glass wares were cleaned with detergent and water, raised with distilled water and acetone before used. Centrifuge and Gas chromatograph couple with mass spectrometer detector (GC-MS) are used for the extraction and analysis respectively.

\section{Sample collection}

Tomatoes samples were collected from three major tomatoes farm land in Zamfara state. Part of each samples were cut and sun dried until it lost all water and moisture contents as it obtained in the traditional way of preserving tomatoes (dry tomatoes).

\section{Samples extraction}

QuEchERS was used for sample preparation as describe by [12].

The samples were grid to homogenized and increase the surface area. $15 \mathrm{~g}$ of homogenized sample was weighed into a cleaned $50 \mathrm{ml}$ test tube; $15 \mathrm{ml}$ of acetonitrile was measured and added to the sample and shake vigorously for 5 minutes. This was done to ensure the organic pesticides residues were dissolved in the solvent and separated from water. $6 \mathrm{~g}$ of $\mathrm{MgSO}_{4}$ and $1.5 \mathrm{~g} \mathrm{NaCL}$ were added to remove the water and maintained the polarity respectively, before centrifuge for 10 minutes at 600rpm. The supernatants was transferred into cleaned test tube follow by adding $150 \mathrm{mg}$ of $\mathrm{MgSO}_{4}$ and shake for 30 seconds and centrifuge for 1 minute at $1500 \mathrm{rmp}$, the cleared extract was used for GC-MS analysis. The process was carryout in all the samples and control.

\section{INSTRUMENTATION}

The analysis was carryout at Nigeria institute of Oceanography and Marine Research (NIOMR), Lagos State Using GC-MS model 7890 Agilent technologies, equipped with auto sampler, capillary column length HP $5 \mathrm{~ms}$ of length $30 \mathrm{~m}$ and internal diameter of $0.320 \mathrm{~mm}$ and 0.25 micrometer. The temperature was program at $60^{\circ} \mathrm{C}$ held for 5 minutes at $8^{\circ} \mathrm{C}$ per minute to the final temperature of $300^{\circ} \mathrm{C}$ held for 30 seconds and the MSD transfer line was held at $300^{\circ} \mathrm{C}$.

Split injection of one microliter was carried out at $300^{\circ} \mathrm{C}$ injector temperature with a purge flow of $3 \mathrm{ml} /$ minute, the carrier gas used was helium, with 
flow rate of $2.17 \mathrm{ml} / \mathrm{minute}$ and the pressure was $150 \mathrm{kpa}$. The interface temperature was $300^{\circ} \mathrm{C}$. The mass spectrometer model 5975 agilent technologies ionization mode was electron impact with ion sources temperature of $230^{\circ} \mathrm{C}$ and in full scan mode ranges from $45-500 \mathrm{M} / \mathrm{Z}$.

Internal standard technique was employed to analyze the fresh and dried extracts. The organochlorine standard used are alpha lindane, delta lindane, endulfan I\&II, heptachlor, aldrin, isodrin, transchloro, DDMU, DDT, P,P-DDE, dieldrin, endrin, mitotane, endrin keto, melhoxychlor and delta pent. The standards are prepare in different concentrations from $0.100 \mathrm{ppm}$ to $2.00 \mathrm{ppm}$ and was used to generate calibration curves for each compound. The efficiency of the method was validated with recoveries of references material without pesticide residues and with four organochlorine pesticide residues spiked $0.1 \mathrm{ppm}$ and $1.0 \mathrm{ppm}$.

The Estimated average daily intake (EADI) and hazard were calculated using equation $1 \& 2$ below:

\section{EADI}

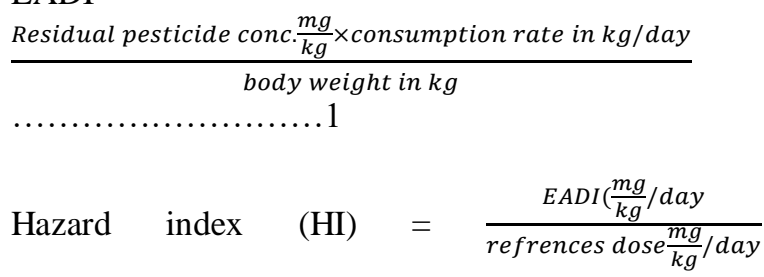
.2

\section{RESULTS AND DISCUSION}

The retention times of the analytes detected in the samples were the same as those of standards and the spectra has a very high match factor.

Table 1 Show the present and the concentration of organochlorine pesticides residue in the fresh and dried tomato extract. Almost all the OCPs determined in the samples are banned in Nigeria according to[23], and in other countries according to FAO/WHO data on banned and restriction of OCPs for agricultural pest control or eradication. $\alpha \mathrm{HCH}$, endosulfan, isodrin and mitotane are above the maximum Residual limit (MRL). However the concentration reduced significantly below the MRL in dried samples, while endosulfan II, mitotane, and deildrine are below the limit of detection in the dried tomato extracts.

Twenty OCPs standards were used for analysis as shown in table I and eight OCPs ; $\alpha \mathrm{HCH}, \beta \mathrm{HCB}$, endosulfan Iand II, isodrin, DDM, deildrin, and mitotane were determined in fresh and dried tomatoes samples extract as shown in table II. Endosulfan II, mitotane and dieldrin are below the limit of detection in the dried tomato extracts, this may attribute to the volatility nature of the OCPs residues as reported by [27].

Most the organochlorine pesticide residues detected in the fresh tomato extract was also reported in a work of [1], [22], [19],[15]. This indicates that farmers may lack information about the potential health risk of OCPs residues in the food product and the dangers to the environments. The continued usage may not be far from the availability and low cost of these chemicals as reported by [1].

Statistical analysis shown significant reduction in concentration of OCPs residues in dried tomatoes compared to the concentration of OCPs residues in the fresh tomato samples at $95 \%$ degree of confidence.

Table 3 shown health risk assessment estimated from the results of eight OCPs residues obtained in this work, using US environmental protection agency data and guideline adopted on dietary pesticide intake on vegetables. Hypothetical body weight of $10 \mathrm{~kg}$ and $70 \mathrm{~kg}$ was adopted for children and adult respectively while $0.037 \mathrm{~kg} /$ person for daily consumption rate of tomato as stated by international food policy research institute and FAO.

It appeared in the table 3.below that all the eight OCPs residues present did not poses health risk except $\alpha \mathrm{HCH}$ and mitotane with hazard index of 2.737 and 1.012 respectively. According WHO if a hazard index is equal or greater than one, such pesticide residue poses a health risk. $\alpha \mathrm{HCH}$ and mitotane pose health hazard to the children when exposed. $\alpha$-Hexachlorocyclohexane $(\alpha-\mathrm{HCH})$ is an isomers of hexachlorocyclohexane $(\mathrm{HCH})$ and byproduct of lindane $(\gamma-\mathrm{HCH})$ and it is typically still contained in commercial grade lindane used as insecticide. As of 2009, the Stockholm Convention on Persistent Organic Pollutants classified $(\alpha-\mathrm{HCH})$ and $(\beta-\mathrm{HCH})$ as persistent organic pollutants (POPs), due to its ability to persistence in the environment, bioaccumulate, biomagnifying, and long-range transport capacity. Exposed to this pesticide residues has a short time effects of causing dizziness, nausea,/vomiting, loss of appetite, and weakness of the body. While the longtime exposure can result to blood disorder, reproductive defect and international agency for research on cancer and US-EPA has also classified them as possibly human carcinogen FAO/WHO 2015. 
International Journal of Engineering Applied Sciences and Technology, 2020

Vol. 5, Issue 8, ISSN No. 2455-2143, Pages 91-96

Published Online December 2020 in IJEAST (http://www.ijeast.com)

TABLE 1: Detectable and non detected OCPs residues in fresh and dried tomatoes $(\mathrm{mg} / \mathrm{kg})$

\begin{tabular}{|c|c|c|c|c|c|c|}
\hline OCPs & $\begin{array}{l}\text { F-tomato } \\
\text { A (mg/kg) }\end{array}$ & $\begin{array}{l}\text { D-tomato } \\
\text { A (mg/kg) }\end{array}$ & $\begin{array}{l}\text { F-tomato B } \\
(\mathrm{mg} / \mathrm{kg})\end{array}$ & $\begin{array}{l}\text { D-tomato B } \\
\text { (mg/kg) }\end{array}$ & MRL mg/kg & WHO/NAFDAC \\
\hline Delta-pent & 0.0115 & ND & ND & ND & & Banned \\
\hline$\alpha$-lindane & 3.6995 & 0.0227 & 2.1603 & 0.0012 & 0.2 & Banned \\
\hline$\beta$-lindane & 0.0100 & ND & ND & ND & 1 & Banned \\
\hline Endosulfan i & 0.1714 & 0.1014 & 0.1678 & 0.15194 & 0.05 & Banned \\
\hline Endosulfan ii & 0.0054 & ND & 0.0074 & 0.00336 & 0.05 & Banned \\
\hline Heptachlor I & ND & ND & ND & ND & 0.01 & - \\
\hline Aldrin & ND & ND & ND & ND & 0.05 & Banned \\
\hline Isodrin & 0.1291 & 0.0132 & 0.1866 & 0.04752 & 0.001 & - \\
\hline Heptachlor II & ND & ND & ND & ND & - & - \\
\hline Trans-nonane & ND & ND & ND & ND & - & - \\
\hline P,p-DDE & ND & ND & ND & ND & - & - \\
\hline Dieldrin & O.0784 & 0.01252 & 0.0308 & 0.00576 & & Banned \\
\hline P,p-DDE & ND & ND & ND & ND & - & - \\
\hline Mitotane & 0.2734 & ND & ND & ND & 0.01 & \\
\hline Endrin ketone & ND & ND & ND & ND & 0.01 & Banned \\
\hline Methoxych & ND & ND & ND & ND & - & - \\
\hline DDMU & 0.0067 & 0.0290 & 0.0290 & 0.0029 & 0.01 & Banned \\
\hline Endrin & ND & ND & ND & ND & 0.01 & - \\
\hline
\end{tabular}

Key: ND- not detectable, F-fresh, D- dried and OCPs means organochlorine pesticide.

TABLE 2: OCPs residues $(\mathrm{mg} / \mathrm{kg})$ in fresh and dried tomatoes

\begin{tabular}{lllllllll}
\hline OCPs & $\boldsymbol{\alpha H C H}$ & $\boldsymbol{\beta H C H}$ & Endosulf & Isodrin & DDM & dieldrin & Endosulf & Mitotane \\
\hline F-TSA & 3.6995 & 0.0100 & 0.1714 & 0.1291 & 0.0067 & 0.0764 & 0.0054 & 0.2734 \\
D-TSA & 0.0227 & 0.00 & 0.1014 & 0.0132 & 0.029 & 0.01252 & 0.00 & 0.00 \\
F-TSB & 2.1603 & 0.00 & 0.1678 & 0.1866 & 0.0290 & 0.0308 & 0.0074 & 0.00 \\
D-TSB & 0.0012 & 0.00 & 0.15194 & 0.04752 & 0.0029 & 0.00576 & 0.00336 & 0.00 \\
\hline
\end{tabular}

Key: F-TSA means fresh tomatoes sample A, D-TSB means dried tomato sample B,

Table 3: Health risk estimation of organochlorine pesticide residues in Tomato

\begin{tabular}{|c|c|c|c|c|c|}
\hline OCPs & $\begin{array}{l}\text { Reference .dose } \\
\text { mg/kg/day }\end{array}$ & $\begin{array}{l}\text { EADI of adult } \\
\text { (mg/kg/day }\end{array}$ & $\begin{array}{l}\text { EADI } \\
\text { children } \\
\text { mg/kg/day }\end{array}$ & Hazard index & Health risk \\
\hline$\alpha \mathrm{\alpha CH}$ & 0.005 & $1.900 \times 10^{-4}$ & $1.37 \times 10^{-4}$ & $\begin{array}{l}\text { AD-0.399 } \\
\text { CHD-2.737 }\end{array}$ & $\begin{array}{l}\text { N0 } \\
\text { YES }\end{array}$ \\
\hline ВНСН & 0.005 & $5.286 \times 10^{-6}$ & $3.70 \times 10^{-6}$ & $\begin{array}{l}\text { AD-7.6 } \times 10^{-8} \\
\text { CHD-7.4 } \times 10^{-4}\end{array}$ & $\begin{array}{l}\text { NO } \\
\text { NO }\end{array}$ \\
\hline Endosulf I & 0.05 & $9.059 \times 10^{-5}$ & $6.341 \times 10^{-6}$ & $\begin{array}{l}\text { AD- } 2 \times 10^{-3} \\
\text { CHD- } 1.3 \times 10^{-5}\end{array}$ & $\begin{array}{l}\mathrm{NO} \\
\mathrm{NO}\end{array}$ \\
\hline Isodrin & 0.01 & $6.824 \times 10^{-4}$ & $4.777 \times 10^{-6}$ & $\begin{array}{l}\text { AD- } 6.8 \times 10^{-4} \\
\text { CHD-4.7 } \times 10^{-4}\end{array}$ & $\begin{array}{l}\mathrm{NO} \\
\mathrm{NO}\end{array}$ \\
\hline DDM & 0.01 & $3.541 \times 10^{-6}$ & $2.449 \times 10^{-5}$ & $\begin{array}{l}\text { AD-3.5 x } 10^{-5} \\
\text { CHD-2.4 } \times 10^{-6}\end{array}$ & $\begin{array}{l}\text { NO } \\
\text { NO }\end{array}$ \\
\hline Dieldrin & 0.001 & $4.838 \times 10^{-5}$ & $2.826 \times 10^{-6}$ & $\begin{array}{l}\text { AD- } 4.0 \times 10^{-4} \\
\text { CHD-2.8 } \times 10^{-2}\end{array}$ & $\begin{array}{l}\text { NO } \\
\text { NO }\end{array}$ \\
\hline Endosulf II & 0.05 & $2.854 \times 10^{-6}$ & $1.778 \times 10^{-6}$ & $\begin{array}{l}\text { AD-5.7 } \times 10^{-5} \\
\text { CHD-3.9 } \times 10^{-5}\end{array}$ & $\begin{array}{l}\mathrm{NO} \\
\mathrm{NO}\end{array}$ \\
\hline Mitotane & 0.001 & $1.445 \times 10^{-6}$ & $1.012 \times 10^{-5}$ & $\begin{array}{l}\text { AD-0.144 } \\
\text { CHD-1.012 }\end{array}$ & $\begin{array}{l}\text { NO } \\
\text { YES }\end{array}$ \\
\hline
\end{tabular}




\section{International Journal of Engineering Applied Sciences and Technology, 2020 Vol. 5, Issue 8, ISSN No. 2455-2143, Pages 91-96 \\ Published Online December 2020 in IJEAST (http://www.ijeast.com)}

KEY: AD is Adult, CHD is Children, and EADI is estimated average daily intake.

\section{CONCLUSION}

The result obtained from the present study shows that organochlorine pesticide residues are present in the fresh and dried tomato from selected farmland in Zamfara State, are $\alpha \mathrm{HCH}, \beta \mathrm{HCH}$, Endosulfan, isodrin, DDM, dieldrin, mitotane and endosulfan with concentration of The $\alpha \mathrm{HCH}$, endosulfan, isodrin and mitotane higher than MRL setup by FAO/WHO. The concentration of OCPs residues in dried tomato samples are below the maximum residual limit. The $\mathrm{HCH}$ and mitotane hazard indexes are high; this may pose health risk to the children when exposed. The study also provides data on organochlorine pesticide residues in the dried tomato sample which shows significant reduction in concentration of the residues. Drying tomato should encourage whenever high level of pesticide residues is suspected in the tomato. Strict regulation and public awareness is also required by regulatory agency to educate the users on the health risk and environmental effect.

\section{ACKNOWLEDGMENT:}

We sincerely acknowledge effort and assistance of management staff and the Technologists in the chemistry laboratory, Federal University of Technology P.M.B 65, Minna, Niger State, Nigeria

\section{REFERENCES}

[1] Ademola., F.A. and Gideon A. (2012). Organochlorine pesticides residues in soil of_Cocoa farms in Ondo State central District, Nigeria: Journal of Environment and Natural Resources Research vol.2 No. 2: doi.org/10.5539/enrr.v2n2p65.

[2] Akinloye, O.A., Adamson, I., Ademuyiwa, O. \& Arowolo, T. A. (2011). Occurrence of paraquat Residues in some Nigeria crops, vegetable and fruits. Journal of Environmental Chemistry and Ecotoxicology, 3(7): 195-198.

[3] Arah, I. K., Kumah, E. K., Anku, E. K., \&Amaglo, H. (2015). An overview of post-harvest losses in tomato production in Africa: causes and possible prevention strategies. Journal of Biology, Agriculture, and Healthcare, 5(16), 78-8

[4] Abdulmalik, I. O., Amonye, M. C., Ambali, A. O., Umeanuka, P. O., \& Mahdi, M. (2014). Appropriate Technology for Tomato Powder Production. International Journal of Engineering Inventions, (3), P 29-34
[5] Adegbola, J. A., Awagu, F., Adu, E. A., Anugwom, U. D., Ishola, D. T., \& Bodunde, A. A. (2012). Investment opportunities in tomato processing in Kano, Nothern Nigeria. Global Advance Research Journal of Agricultural Science, l(10), P 288-297

[6] Adenegan, K. O., \& Adeoye, I. B. (2011). Price analysis of tomato in rural and urban retail markets of

Oyo State. International Journal of Agricultural Economics \& Rural Development, 4(2), 90-96.

[7] Akinmutimi A.H. (2006) Chemical analysis of Nutritive value of raw and processed

Jack fruit seeds (Artocaptus heterophyllus) Agricultural Journal. (1):266-271.

[8] Aliyu L., Usman A., \& Mani U. (2018) Evalution of nutritional composition of healthy and infected dried

Tomato chips sold in sokoto metropol. A journal of innovation food.6 (2): 1-4

[9] AOAC, (2005). Official methods of analysis of the AOAC International. (18thed.). Gaithersburg (USA): AOAC International; 2005.

[10] AOAC, (2003). Official Methods of Analysis, Association of Official Analytical Chemist, Wahington, D.C, 2003

[11] AOAC, (2000). Official method of Analysis of Association of Analytical Chemists Intrnational. 17 $7^{\text {th }}$ Edition, Horowitz, Maryland, 2000.

[12] ATSDR (2013). Toxicological profile for endosulfan. U.S department of health and huma service

[13] ATSDR (2002). A gency for toxic substances and disease registry. Toxicological profile for DDT, DDE, DDM, DDMU. U.S department of health and human service.

[14] Bozena, L., Elmira, A., Abai, A., Piotr, K., Kazbeck, T. \& Alina Li.(2015). Studies of pesticide Residues in tomatoes and cucumbers from Kazakhstan and the associated health risks. A

Journal of Environ moit Assess. Doi: 10.1007/s10661-015-4818-6. 
[15] Buba, M., Maitera, O.N., Dass, P.M \& Abraham, E.A.(2017). Determination of organochchlorine

pesticides residues level in some selected vegetable cultivated in Mubi-north Mubisouth LGA, Adamawa state,Nigeria. Journal Applied Science, 2(1) 25- 40

[16] FAO \&WHO (2013). Pesticide residues in food and feed codex Alimentarium commission. Joint FAO and WHO food standard program. Roma Italy

[17] FAO/WHO (2015). Pesticide residues in food and feed, Glossary of terms, retrieved: 2015 John, A,M., Farhat, A, K.\& Ester, H.J.(2017). Assessment of Pesticide Residues in Tomatoes and Watermelons (Fruits) from markets in Dares Salaam, Tanzania. Journal of Appl. Sci. Environ. 21. (3) . 497-501.

[18] Ibrahim E. G., Yakubu N., Nnamonu J., Yakubu M. (2018). Determination of organochlorine pesticide residues in pumpkin, Spinach, and Sorrel leave Grown in Akwanga, Nassarawa State, Nigeria. Journal of environmental protection vol.9, 508-515.

[19] Joseph,C.A., Lami , J., Zaynab, M.C., Zakari, M. \& Fanna, I.A.(2014). Determination of some Organochlorine pesticide Residues in vegetable and soil sample from Alau Dam and Gongulong Agricultural sites, Borno State, North Eastern Nigeria. Journal of world Academy of Science, Engineering and Technology. Vol.8,No:4.

[20] Linda , D., Ahemad, A., \& Komla, A.D.(2016). Pesticide use in the production of tomato (Lycopersicum L.) in some areas of Northen Ghana. Journal of Agricultural research.

$$
\text { Vol.11(5). 352-35. }
$$

[21] Mohamed H. Shiboob (2012). Residues of Dimethoate and Profenofos in Tomato and Cucumber,

and Dissipation during the removal within home processing method. Journal of Env. Sci.
vol.23, No.1, PP: 51-63.

Doi:10.4197/met.23-1.4.

[22] Njoku K., Ezeh, C., Obidi, F.O., \& Akinola, M.O.,(2017) Assessment of pesticide residues level in

vegetables sold in some market in Lagos State, Nigeria Journal of Biotech. Vol.32.63-60.

Doi:org/10.4314/njb.
[23] National Agency for food and Drug administration and control (NAFDAC) (2017). Pesticides regulation

And guide line for usage. As approved by governing council. Nigeria.

[24]Nsikak, U. B.\& Aruwajoye,I. O. (2011). Assessment of contamination by organochlorine pesticides

in solanum lycopersicum $L$. and capsicum annum L.: A market survey in Nigeria.. A

Africa journal of Environmental Science and Technology Vol.5(6), 437-442.

[25] Nosakhare,O., Dirisu, A.,\& Olomukoro, J.O.(2012). Implications of pesticide usage in Nigeria.

Journal of Tropical freshwater Biology, Vol.21(1) 15-25.Doi:org/10.4314/tfb.v2lil.2

[26] Ojo, J. (2016) pesticide and its Health in Nigeria. Ife Journal of science. Vol.18 no.4

[27]Rudel, H. (1997). Volatilization of pesticides from soil and plant surface. Journal of chemosphere, Vol. 35, No.1-2.

[28]Victoria, K., Neema, K., \& Martin, K. (2016) Pesticide exposure from fresh Tomatoes and its relationship with pesticide application practices in Meru district. Journal of food science \& technology. Doi: org/10.1080/23311932.2016.1196808. 